\title{
THE EFFECTS OF SELECTION FOR YIELD IN WHEAT
}

By S. W. BOYCE, L. G. L. COPP and O. H. FRANKEL Wheat Research Institute, Christchurch, New Zealand

\section{INTRODUCTION}

Received 3.ix.46

IN the introductory paper to this series, Frankel (1946) has discussed the general problems encountered in selection for total yield. Once the maximum resistance is reached to factors which limit yield and whose effects are observable, further progress can be achieved only by increasing the components of yield.

The principal difficulty at this stage arises from the fact that yield components are so subject to environmental variation that the recognition of favourable genotypes is difficult even in replicated yield trials. Genetic concepts require segregating populations greatly exceeding in number those which can normally be included in such trials. Hence the efficiency of selection of single plants and their immediate progenies constitutes a major problem in selecting for yield itself.

This paper examines the efficiency of selection of single plants and their progenies in a practical plant breeding scheme on wheat. It seeks an answer to the following questions :-

A (I) Are the effects of selection in one generation, on the yield of the next, large enough to overcome the effects of environmental variation?

(2) Is selection for components of yield likely to make greater advances than selection for yield alone?

(3) Is selection for an agronomic character, such as straw length, itself not a component of yield, likely to have an effect on yield in the following generation ?

B (I) Is selection by eye-judgment, instead of actual measurement, effective in retaining a large proportion of the material which would have been selected by measurement?

\section{MATERIAL AND METHODS}

The material used was part of an $\mathrm{F}_{2}$ generation of a compound cross $\left(F_{1}\right.$ Holdfast $\times$ Tainui) $\times$ Cross 7 .

The use of crosses between two $F_{1} s$ - or in this case an $F_{1}$ and a third variety-enables the desirable characters of several varieties to be brought together for simultaneous selection. For gene differences 
in the first crosses, a compound $F_{2}$ is in fact an $F_{3}$; for those in the second cross it is an $F_{2}$. Hence a compound $F_{2}$ possesses high intra-plot segregation combined with inter-plot segregation, the measure of both depending on the genetic differences between the parents concerned.

In practice, more often than not selection in self-fertilised plants does not commence until an advanced hybrid generation has been reached. Since in this study mean values per plot are used in the $\mathbf{F}_{\mathbf{3}}$ generation, the effects of selection in $F_{2}$ and, say, $F_{8}$ would differ only if $F_{3}$ plots possessed genetic skewness due to dominance.

Parents

\begin{tabular}{|c|c|c|c|c|c|c|}
\hline \multirow{2}{*}{ Name } & \multirow{2}{*}{ Origin } & \multirow{2}{*}{ Agronomic characteristics } & \multicolumn{4}{|c|}{$\begin{array}{l}\text { Yield and yield } \\
\text { components r } 944\end{array}$} \\
\hline & & & eng & e & $\mathbf{n}$ & $g$ \\
\hline Holdfast & $\begin{array}{l}\text { Produced by Plant Breed- } \\
\text { ing Institute, Cambridge }\end{array}$ & $\begin{array}{l}\text { Yield-usually below or } \\
\text { close to-Cross } 7 \text {. Shat- } \\
\text { tering of grain a serious } \\
\text { fault }\end{array}$ & $\cdots$ & $3 \cdot 08$ & $\cdots$ & $36 \cdot 7$ \\
\hline Tainui & $\begin{array}{l}\text { Produced by New Zealand } \\
\text { Wheat Research Insti- } \\
\text { tute. Selection from } \\
\text { Portuguese sample }\end{array}$ & $\begin{array}{l}\text { Yield-close to or above } \\
\text { Cross } 7 \text {. Used as a } \\
\text { spring wheat }\end{array}$ & $3 \cdot 43$ & $3 \cdot 77$ & $17 \cdot 2$ & $53 \cdot 8$ \\
\hline Cross 7 & $\begin{array}{l}\text { Produced by New Zealand } \\
\text { Wheat Research Insti- } \\
\text { tute. Cross: Tuscan } \times \\
\text { White Fife }\end{array}$ & $\begin{array}{l}\text { Principal standard wheat } \\
\text { in New Zealand }\end{array}$ & $4 \cdot 22$ & $4 \cdot 51$ & $23 \cdot 7$ & $40 \cdot 0$ \\
\hline
\end{tabular}

Cf. p. 226

The tendency to shattering, inherited from Holdfast, materially weakened the $\mathrm{F}_{2}-\mathrm{F}_{3}$ correlations.

History of cross

\begin{tabular}{|c|c|c|}
\hline Year & Generation & Segregation \\
\hline $\begin{array}{l}1940 \\
1941 \\
1942 \\
1943 \\
1944\end{array}$ & $\begin{array}{l}\text { Cross : Holdfast } \times \text { Tainui } \\
\text { Compound cross : (F }: \text { Holdfast } \times \text { Tainui }) \times \text { Cross } 7 \\
\text { Compound } F_{1} \\
\Rightarrow, \quad F_{2} \\
, \quad F_{3}\end{array}$ & $\begin{array}{l}\text { None } \\
\text { None } \\
\text { Intra-plot or inter-plant } \\
\text { Intra-plot and inter-plot } \\
\text { Intra-plot, intra-family, } \\
\text { inter-family }\end{array}$ \\
\hline
\end{tabular}

A block of five compound $F_{2}$ plots and their $F_{3}$ progeny was studied. In $F_{3}$, 200 progenies of both unselected and selected $F_{2}$ plants were raised, affording a test for inter-plot selection in $F_{3}$ and for selection in $F_{2}$. In the test for eye-judgment, the $F_{2}$ was selected by two, the $F_{3}$ by three observers, working independently. 
Throughout the discussion the following terms and symbols are used :-

Plot : Progeny of a single plant-contains about 50 plants.

Family: Group of $F_{3}$ plots containing progenies of plants from a common parent plot.

e : number of ears per plant.

$\mathrm{n}$ : number of grains per ear.

$\mathrm{g}$ : average weight of one grain in $\mathrm{mg}$.

ng: weight of grain per ear in mg.

eng : yield per plant $\left(\mathrm{F}_{2}\right)$ or mean yield per plant $\left(\mathrm{F}_{3}\right)$.

\section{A. THE EFFECT OF SELECTION IN $F_{2}$ ON YIELD IN $F_{3}$}

The $F_{2}$ plants were arrayed plotwise and again "over all plots," in order of their measurements of eng and its components. Selection limits were set at to and 20 per cent. of each array. The mean yields per plant of the $F_{3}$ progenies raised from these top fractions were averaged, and related to the mean yield per plant of the whole corresponding $\mathrm{F}_{3}$ family (table $\mathrm{I}$ ).

TABLE I

Effect of selecting for eng and its components in $F_{2}$ on eng in $F_{3}$

\begin{tabular}{|c|c|c|c|c|c|c|c|c|}
\hline \multirow{2}{*}{$\begin{array}{c}F_{2} \text { plots } \\
\text { or } \\
F_{3} \text { families }\end{array}$} & \multirow{2}{*}{$\begin{array}{l}\text { Number of } \\
F_{2} \text { plants } \\
\text { and } F_{3} \\
\text { plots }\end{array}$} & \multirow{2}{*}{$\begin{array}{l}\text { Level of } \\
\text { selection }\end{array}$} & \multicolumn{5}{|c|}{$\begin{array}{l}\text { Percentage increase over unselected } \mathbf{F}_{3} \\
\text { family means by selection for eng and } \\
\text { its components in } \mathbf{F}_{2}\end{array}$} & \multirow{2}{*}{$\begin{array}{l}\text { Per cent. } \\
\text { increase by } \\
\text { selecting in } \\
\mathbf{F}_{2} \text { for } \\
\text { short straw }\end{array}$} \\
\hline & & & eng & e & $\mathbf{n}$ & $\mathrm{g}$ & ng & \\
\hline I659 & $4^{2}$ & $\begin{array}{l}\text { Per cent. } \\
\text { ro } \\
20\end{array}$ & $\begin{array}{l}16.5 \\
13.1\end{array}$ & $\begin{array}{l}5 \cdot 8 \\
8 \cdot 8\end{array}$ & $\begin{array}{l}12 \cdot 0 \\
12 \cdot 0\end{array}$ & $\begin{array}{l}-\mathrm{II} \cdot 0 \\
-\mathrm{I} 5.3\end{array}$ & $\begin{array}{l}17 \cdot 1 \\
10 \cdot 1\end{array}$ & $\begin{array}{r}-10.5 \\
0.2\end{array}$ \\
\hline I66o & 45 & $\begin{array}{l}10 \\
20\end{array}$ & $\begin{array}{l}-2 \cdot 7 \\
-7 \cdot 7\end{array}$ & $\begin{array}{r}-12.1 \\
-9.5\end{array}$ & $\begin{array}{r}-13.0 \\
-8.0\end{array}$ & $\begin{array}{r}-13.0 \\
-13.9\end{array}$ & $\begin{array}{r}-15 \cdot 7 \\
-8 \cdot 0\end{array}$ & $\begin{array}{l}-8 \cdot 0 \\
-5 \cdot 4\end{array}$ \\
\hline I $66 \mathrm{I}$ & 34 & $\begin{array}{l}10 \\
20\end{array}$ & $\begin{array}{l}34.5 \\
13.8\end{array}$ & $\begin{array}{r}26 \cdot 8 \\
6 \cdot 4\end{array}$ & $\begin{array}{r}5.6 \\
11.7\end{array}$ & $\begin{array}{r}-12 \cdot 7 \\
-5.1\end{array}$ & $\begin{array}{r}4.4 \\
19.4\end{array}$ & $\begin{array}{r}-16 \cdot 3 \\
3.8\end{array}$ \\
\hline I 663 & 35 & $\begin{array}{l}10 \\
20\end{array}$ & $\begin{array}{r}34.5 \\
-1 \cdot 9\end{array}$ & $\begin{array}{l}2 \cdot 0 \\
\ldots\end{array}$ & $\begin{array}{r}12 \cdot 2 \\
5.5\end{array}$ & $\begin{array}{l}\text { I } 14 \\
19.6\end{array}$ & $\begin{array}{l}18 \cdot I \\
14 \cdot 0\end{array}$ & $\begin{array}{l}-11 \cdot 9 \\
-14 \cdot 1\end{array}$ \\
\hline I 664 & 44 & $\begin{array}{l}10 \\
20\end{array}$ & $\begin{array}{l}-2 \cdot 5 \\
-3 \cdot I\end{array}$ & $\begin{array}{r}-3 \cdot 2 \\
2 \cdot 6\end{array}$ & $\begin{array}{l}-5.9 \\
-3.6\end{array}$ & $\begin{array}{r}\mathrm{I} \cdot 4 \\
-54\end{array}$ & $\begin{array}{r}-4 \cdot 2 \\
3 \cdot 6\end{array}$ & $\begin{array}{r}10 \cdot 4 \\
9 \cdot 0\end{array}$ \\
\hline $\begin{array}{l}\text { Over } \\
\text { all } \\
\text { plots }\end{array}$ & 200 & $\begin{array}{r}5 \\
10 \\
20\end{array}$ & $\begin{aligned} 9 \cdot 4 \\
9 \cdot 4 \\
13 \cdot 1 \\
10 \cdot 8\end{aligned}$ & $\begin{array}{r}\mathrm{Ir} \cdot 7 \\
8 \cdot 5 \\
2 \cdot 5\end{array}$ & $\begin{array}{l}-5 \cdot 2 \\
-4 \cdot 4 \\
-6 \cdot 7\end{array}$ & $\begin{aligned} & 14.6 \\
- & 14.6 \\
& \quad \cdots\end{aligned}$ & $\begin{array}{r}-1 \mathrm{I} \cdot 5 \\
3 \cdot \mathrm{I} \\
6 \cdot 8\end{array}$ & $\begin{array}{l}-22 \cdot 0 \\
-11 \cdot 8 \\
-5 \cdot 8\end{array}$ \\
\hline
\end{tabular}

(1) Efficiency of selection for yield (eng)

(a) Selection within plots (plantwise). Selection for eng in $\mathbf{F}_{2}$ was successful in raising the mean yield per plant in only two of the five 
$F_{3}$ families. Owing to the small number of $F_{2}$ plots tested this result is inconclusive (table $\mathrm{I}$, column 4 ).

(b) Selection between plots (plotwise). The correlation between the mean yields per plant of the $F_{2}$ plots and the resulting $F_{3}$ families $\left(\mathrm{r}=\cdot 79^{ \pm} \cdot 17\right)$ indicates that selection between plots was justified.

(c) Selection over all plots (plantwise). The selection in $\mathbf{F}_{2}$ over all plots was successful in raising the mean yield of the progenies of selected plants above the mean yield of the unselected $F_{3}$ population (table I, column 4, bottom line). This was achieved, in part, by the differential selection between plots, since those with the highest means had greater than random representation in the over-all sample. This fact, however, fails to account for the whole of the increase of I0.8 per cent. at the 20 per cent. selection level; for a random sample taken within plots in the same proportions raises the mean of the $F_{3}$ by only 3.4 per cent. This indicates some success of plantwise selection.

\section{(2) Efficiency of selection for yield components $(e, n, g)$}

Using Fisher's (1936) concept of discriminant functions, H. F. Smith (1936) suggested a method for selection based on the inequality of environmental variances of the individual components of yield. $\mathrm{He}$ found that between wheat varieties, selection based almost entirely on grain weight was most effective. Whether this principle could be used to discriminate between individuals of an early hybrid generation has yet to be established.

In this material (table 1 , columns $5-8$ ) the only yield component which consistently varies with yield is $n$. The range of variation of $n$, however, is in general below that of eng. Since $n$, which requires a count, is a good deal more cumbersome to establish than eng which is based on weight, no advantage would accrue from the use of $n$ in preference to that of eng.

(3) The effect of selection in $F_{2}$ for a character, not itself a component of yield, on yield in $F_{3}$

Table I, column 9, shows that straw length and yield are not wholly unconnected; yet the direction of the correlation, as well as its strength, varies from plot to plot. The effect on yield of selection for short straw is therefore unpredictable. In this material the conclusion is justified that should straw length be of relevance, selection for yield is not likely to be affected seriously by a consideration of this character in addition to yield.

\section{B. THE EFFICIENCY OF SELECTION BY EYE-JUDGMENT}

From the foregoing sections it is evident that in this material eng is the only reliable measure in selecting for yield. However, the weighing of each plant is cumbersome and limits the size of the 
material which can normally be handled. Selection by eye-judgment on the other hand is comparatively rapid and facilitates selection from a large population. Its efficiency in selecting for yield is examined in this section.

\section{(1) Efficiency of selection by eye in $F_{2}$ (plantwise)}

(a) Selection within plots. Fig. $\mathrm{r} a$ shows that both workers tended to select plants with yields well above the mean yield of each plot.

(b) Selection between plots. The proportion of plants selected within each plot varied with the mean yield per plot (fig. $\mathrm{r} a$ ). This difference in intensity of selection, between plots, resulted in an over-all increase in mean yield per plant regardless of the efficiency of single plant selection ( $c f$. p. $226(c)$ ).

(c) Over all plots. The relative efficiency of selection was measured by the proportions of the highest yielding twentieth, tenth and fifth (by measurement) of the whole population, which were detected by the selectors; that of rejection, by the proportions rejected in the remainders. There was no attempt made to group the selected plants by eye-judgment (table 2). The distributions of the unselected population, and the plants selected by either A or B are shown in fig. 2 .

TABLE 2

Efficiency of eye-selection and rejection in $F_{2}$

\begin{tabular}{|c|c|c|c|c|c|c|c|}
\hline \multirow{2}{*}{$\begin{array}{l}\text { Level of top } \\
\text { fraction }\end{array}$} & \multicolumn{2}{|c|}{5 per cent. } & \multicolumn{2}{|c|}{ Io per cent. } & \multicolumn{2}{|c|}{20 per cent. } & \multirow{2}{*}{$\begin{array}{c}\begin{array}{c}\text { Ioo } \\
\text { per cent. }\end{array} \\
\text { Selected }\end{array}$} \\
\hline & Selected & Rejected & Selected & Rejected & Selected & Rejected & \\
\hline $\begin{array}{c}\text { Selector A } \\
\begin{array}{c}\mathbf{A}+\mathbf{B} \\
\mathbf{A} \text { or } \mathbf{B}\end{array}\end{array}$ & $\begin{array}{c}\text { Per cent. } \\
67 \\
92 \\
67 \\
92\end{array}$ & $\begin{array}{c}\text { Per cent. } \\
86 \\
90 \\
93 \\
82\end{array}$ & $\begin{array}{c}\text { Per cent. } \\
61 \\
78 \\
57 \\
83\end{array}$ & $\begin{array}{c}\text { Per cent. } \\
88 \\
93 \\
95 \\
85\end{array}$ & $\begin{array}{c}\text { Per cent. } \\
45 \\
47 \\
34 \\
58\end{array}$ & $\begin{array}{c}\text { Per cent. } \\
90 \\
94 \\
96 \\
88\end{array}$ & $\begin{array}{c}\text { Per cent. } \\
17 \\
14 \\
10 \\
21\end{array}$ \\
\hline
\end{tabular}

Selected $=\left(\frac{\text { selection by eye }}{\text { selection by weight }} \times 100\right)$

Rejected $=\left(\frac{\text { rejection by eye }}{\text { rejection by weight }} \times 100\right)$

The success of selection at the 5 per cent. level and the partial failure at 10 and 20 per cent. is due to the wide difference between the yields of a few top plants and the mean yield of the population, as illustrated in fig. 1 . With a decreasing intensity of selection, this difference also decreases, and selection becomes more difficult. At the 20 per cent. level, the yields of the majority of the plants differ only slightly from the population mean and selection is more or less random. At this stage personal bias would seriously modify selection.

Selector A, while retaining a larger proportion of the whole population, was less efficient than B in detecting the top fraction, 


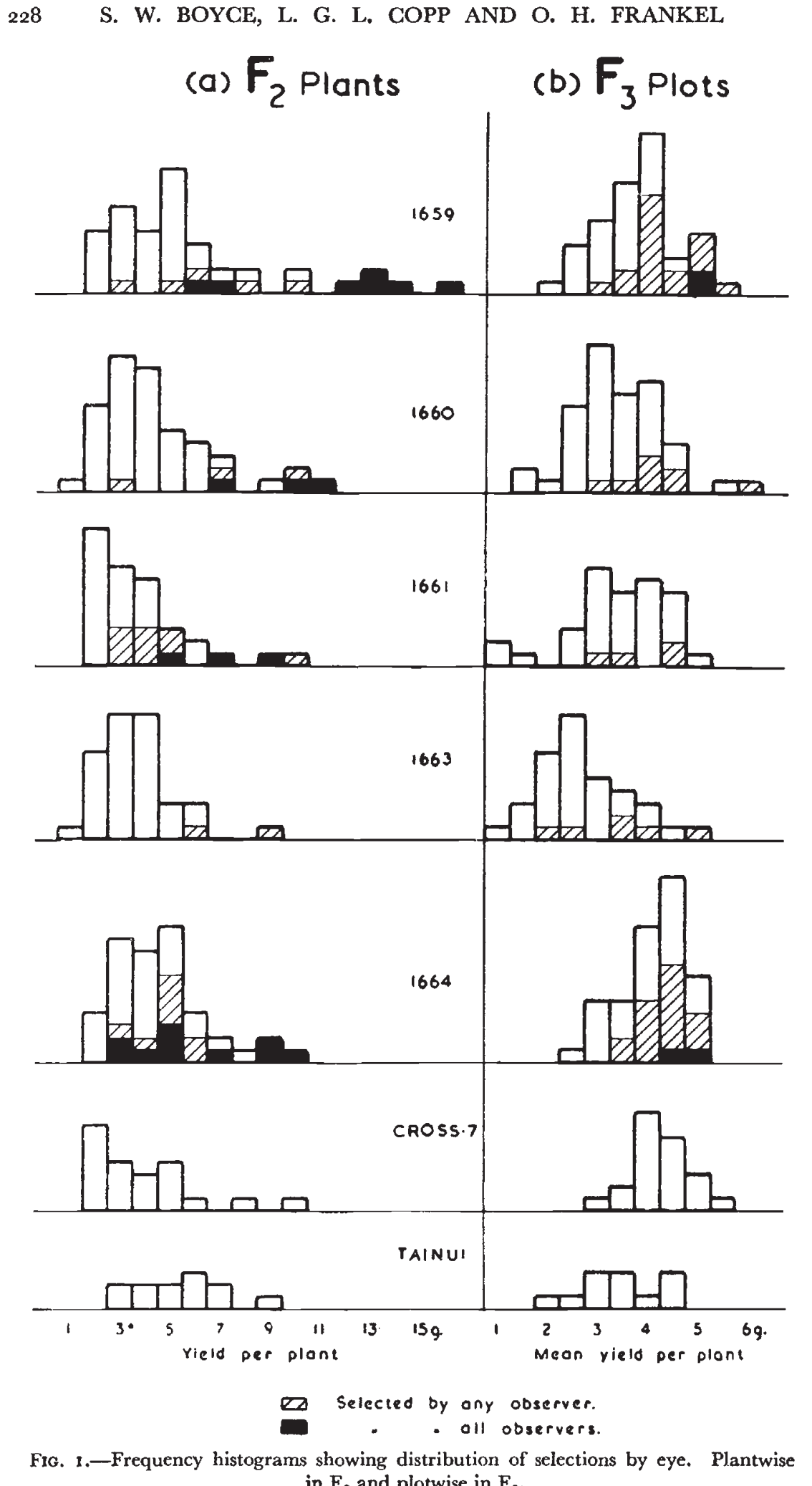


and in rejecting unwanted material. This may have been due to a bias in selecting for plant type. A comparison of the means of yield components and mean straw length of selected and rejected plants

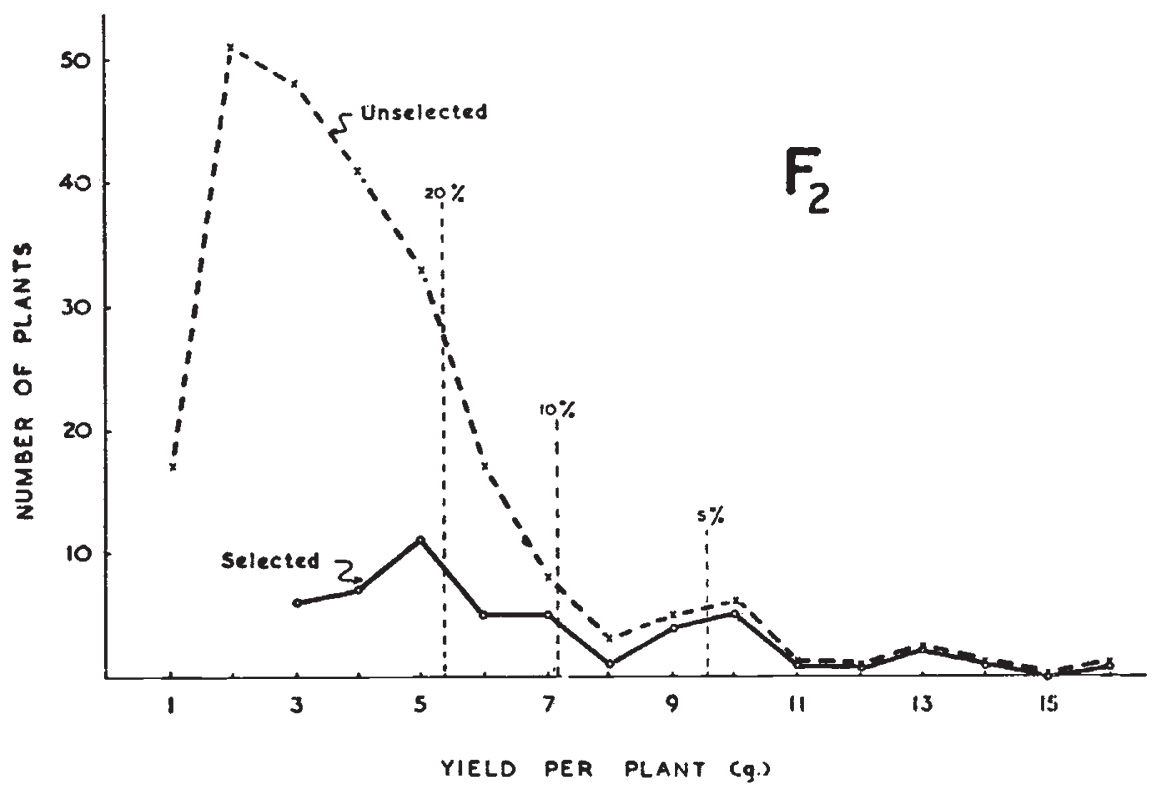

FrG. 2.-Distributions of the unselected $F_{2}$ population and the plants selected by eye.

shows that selector A tended to give greater weight to short straw than selector B. In this generation short straw was negatively correlated with yield, which may explain in part the lower efficiency of A. Both selectors rejected a few high yielding plants with signs of shattering.

(2) Efficiency of selection by eye in $F_{3}$ (plotwise)

Each $F_{3}$ family contained five standard plots of Cross 7 , two of Tainui and two of Holdfast. It was assumed that variations between the yields of consecutive Gross 7 plots might indicate fertility trends and provide the observer with a standard of comparison. It was found that the mean yield per plant of the $F_{3}$ families was correlated with the mean yield of the corresponding Cross 7 standard plots $\left(\mathrm{r}=\mathrm{8}_{5}\right)$. Adjustment of the $\mathrm{F}_{3}$ mean yields according to the variation between the sets of standards removes most of the variation between families.

The number of plots selected from each family show that no observer used the Cross 7 plots as an aid to selection between families (table 3 ).

(a) Within families. Environmental variations within plots and between plots render small differences between plots difficult to detect ; especially when they are not adjacent. Yet, as in $F_{2}$, all 
observers tended to select plots with yields above the mean yield of each family (fig. I $b$ ).

TABLE 3

Differential selection between families, related to family mean

\begin{tabular}{|c|c|c|c|c|c|c|}
\hline \multirow{2}{*}{ Family no. } & \multicolumn{2}{|c|}{ Mean yield per plant } & \multicolumn{4}{|c|}{ No plots selected } \\
\hline & $F_{3}$ families & $\begin{array}{l}\text { Cross } 7 \text { standards } \\
\text { within families }\end{array}$ & A & $\mathbf{B}$ & C & ANY \\
\hline $\begin{array}{c}1659 \\
1660 \\
1661 \\
1663 \\
1664 \\
\text { Over all plots }\end{array}$ & $\begin{array}{l}3 \cdot 74 \\
3 \cdot 39 \\
3 \cdot 39 \\
2 \cdot 70 \\
4 \cdot 11 \\
3 \cdot 50\end{array}$ & $\begin{array}{l}4 \cdot 39 \\
4 \cdot 09 \\
3 \cdot 84 \\
3 \cdot 94 \\
4 \cdot 80 \\
4 \cdot 22\end{array}$ & $\begin{array}{r}13 \\
1 \\
3 \\
4 \\
14 \\
35\end{array}$ & $\begin{array}{r}8 \\
3 \\
1 \\
1 \\
4 \\
17\end{array}$ & $\begin{array}{r}13 \\
4 \\
2 \\
3 \\
8 \\
30\end{array}$ & $\begin{array}{r}20 \\
8 \\
4 \\
6 \\
19 \\
57\end{array}$ \\
\hline
\end{tabular}

(b) Between families. There are differential intensities of selection in the five families, but their effects on yield are less pronounced than in $\mathrm{F}_{2}$.

(c) Over all families. Distributions of the unselected population and the plots selected by each and any of the observers are shown in fig. 3. Selection has increased the proportion of high yielding

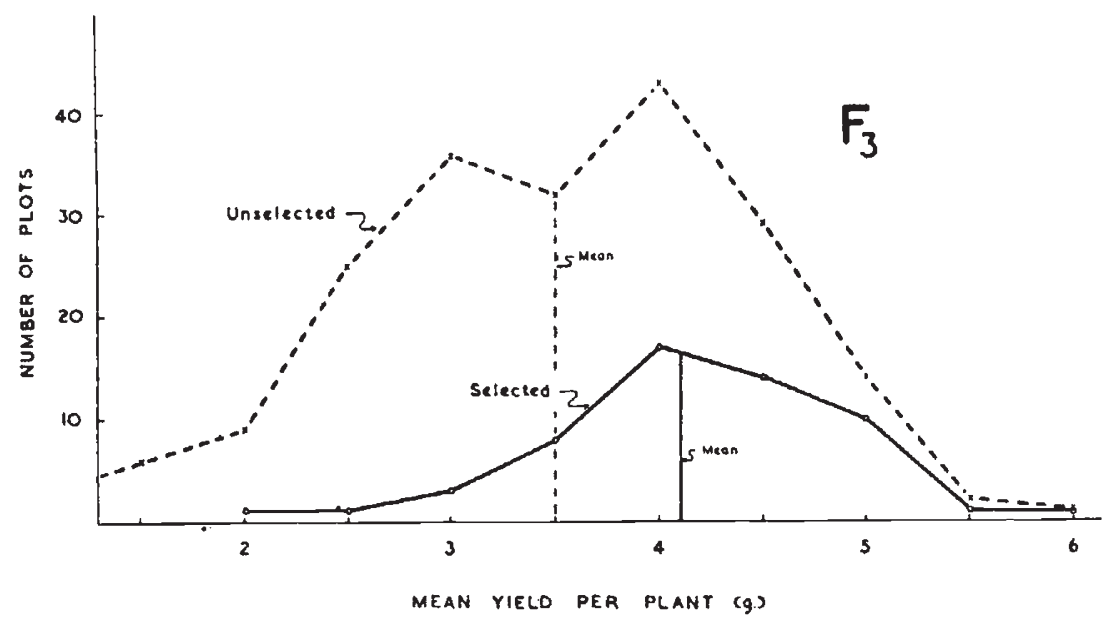

Frg. 3.-Distributions of the unselected $F_{3}$ population and the plots selected by eye by each and any of the three observers.

plots. However, here selection covers the full range, for estimating plot yields is more complex than estimating plant yields.

The primary aim of selection at this stage is to retain as much as possible of the top fraction; a secondary aim is to reject as much as possible of the remainder. Table 4 shows how the judgment of the three selectors was influenced by the two considerations. A 
and $\mathrm{C}$ retained, roughly, twice as many plots as $\mathrm{B}$. The latter selector, however, secured only half the proportion of high yielding plots, whilst his efficiency of rejection was not much better than that of $\mathrm{A}$ and $\mathrm{C}$. This argues for a relatively low intensity of selection when using eye-judgment.

TABLE 4

Efficiency of eye-selection and rejection in $F_{3}$

\begin{tabular}{|c|c|c|c|c|c|c|c|}
\hline \multirow{2}{*}{$\begin{array}{l}\text { Level of top } \\
\text { fraction }\end{array}$} & \multicolumn{2}{|c|}{5 per cent. } & \multicolumn{2}{|c|}{ Io per cent. } & \multicolumn{2}{|c|}{20 per cent. } & \multirow{2}{*}{$\mid \begin{array}{c}100 \\
\text { per cent. }\end{array}$} \\
\hline & Selected & Rejected & Selected & Rejected & Selected & Rejected & \\
\hline 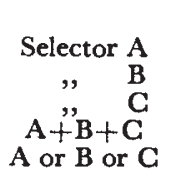 & $\begin{array}{l}\text { Per cent. } \\
40 \\
10 \\
50 \\
\text { I0 } \\
60\end{array}$ & $\begin{array}{c}\text { Per cent. } \\
84 \\
92 \\
87 \\
98 \\
73\end{array}$ & $\begin{array}{c}\text { Per cent. } \\
50 \\
25 \\
50 \\
15 \\
70\end{array}$ & $\begin{array}{c}\text { Per cent. } \\
86 \\
93 \\
89 \\
99 \\
76\end{array}$ & $\begin{array}{c}\text { Per cent. } \\
45 \\
20 \\
35 \\
10 \\
60\end{array}$ & $\begin{array}{c}\text { Per cent. } \\
89 \\
94 \\
90 \\
100 \\
79\end{array}$ & \begin{tabular}{|c} 
Per cent. \\
18 \\
9 \\
15 \\
2 \\
29
\end{tabular} \\
\hline
\end{tabular}

Selected $=\left(\frac{\text { Selection by eye }}{\text { Selection by weight }} \times 100\right)$

Rejected $=\left(\frac{\text { Rejected by eye }}{\text { Rejected by weight }} \times 100\right)$

(3) Effect of selection by eye in $F_{2}$ on yield in $F_{3}$

In four of the five families, the mean yield per plant of the progenies of plants selected in $F_{2}$ was above the mean yield per plant of the unselected family. The varying intensity of selection between $\mathrm{F}_{2}$ plots

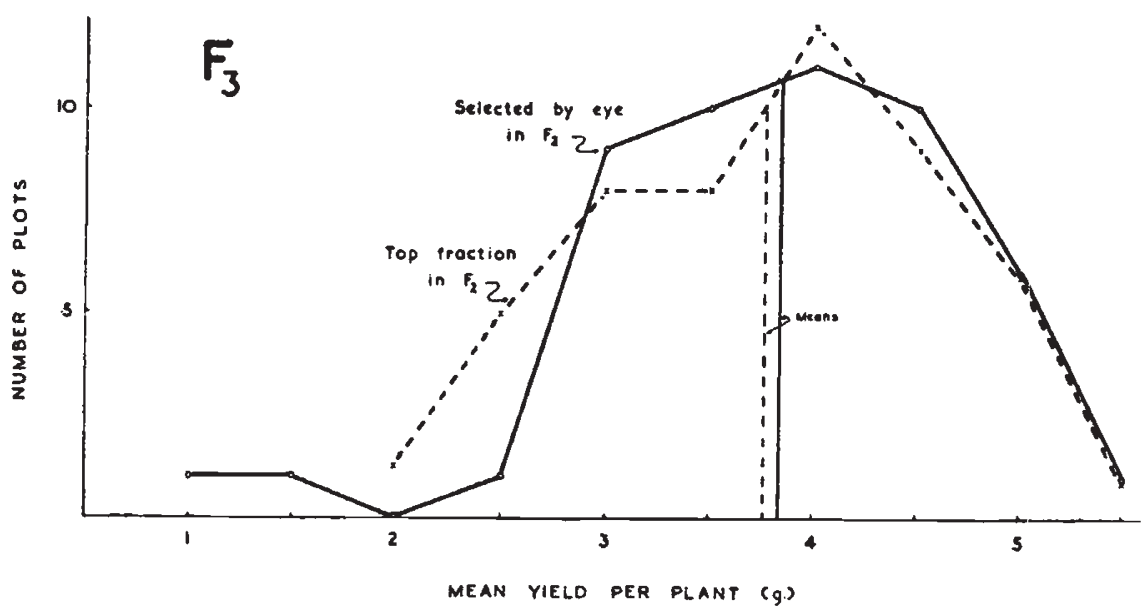

Fig. 4.-Distributions of the $F_{3}$ plots selected by eye in $F_{2}$ and an equal number selected by measurement in $F_{2}$.

is effective in raising the mean yield of the selected progenies above the over-all mean ( $c f$. p. $226(c))$. The distribution of the progenies of $F_{2}$ plants selected by eye and by measurement are shown in fig. 4 . 
(4) Effect of selecting in $F_{3}$ the progenies of selected $F_{2}$ plants

In the previous section all plots were examined, including those whose parent plants had been rejected in $F_{2}$, and a number of such " rejected" plots have been selected in $F_{3}$. We now must determine whether selection between plots grown from selected $F_{2}$ plants resulted in real progress. Such selection was handicapped by the fact that all plots were grown in consecutive order, " $F_{2}$ selected " being mixed at random among " $F_{2}$ rejected," thus making comparisons within " $F_{2}$ selected" more difficult. Nevertheless, the mean yield of reselected $F_{3}$ plots is higher than that of $F_{3}$ plots grown from all selected $F_{2}$ plants.

\begin{tabular}{|c|c|c|}
\hline & $\begin{array}{l}\text { Mean yield per plant } \\
\text { of } F_{3} \text { plots }\end{array}$ & $\begin{array}{c}\text { Number of } \\
\text { plots }\end{array}$ \\
\hline $\begin{array}{l}\text { Unselected } F_{3} \text { population } \\
\text { All plots selected in } F_{3} \\
\text { All plants selected in } F_{2} \\
\text { Plants selected in } F_{2} \text {, plots rejected in } \dot{F}_{3} \\
\text { Plants selected in } F_{2} \text {, plots selected in } F_{3}\end{array}$ & $\begin{array}{l}3 \cdot 50 \\
4 \cdot 11 \\
3 \cdot 84 \\
3 \cdot 47 \\
4 \cdot 29\end{array}$ & $\begin{array}{r}200 \\
57 \\
49 \\
28 \\
21\end{array}$ \\
\hline
\end{tabular}

\section{CONCLUSION AND SUMMARY}

I. In an $F_{2}$ from a compound cross, plotwise selection was successful, but plantwise selection within plots was successful only in those plots which had previously been selected plotwise. This may have been due to differential segregation or to environmental variation between plots. Plantwise selection over all plots was successful since it took advantage of segregation both within and between plots.

Whilst these conclusions provide some evidence of positive selection for yield in plants and in non-replicated plots of a selffertilising crop, they emphasise the complexities and uncertainties of the process. Further studies have been commenced with a view to improving the efficiency of selection.

2. Efficiency of selection was not improved by using yield components in place of yield itself.

3. Selection for an agronomic character, viz. length of straw, did not seriously affect the efficiency of selection for yield.

4. Eye-judgment of single plants, when compared with selection based on weight, was more successful the higher the intensity of selection (table 2). Eye selection of plots was not as successful as that of plants (table 4 ).

Such comparisons are apt to reveal personal bias. The results show that eye selection by more than one observer raises considerably the efficiency of selection.

5. Selection by eye-judgment was as successful as selection by weight in raising the mean yields of the progenies. 
6. The progenies of selected $F_{2}$ plants which were selected in $F_{3}$, gave higher mean yields than the progenies selected in $F_{2}$ but rejected in $\mathrm{F}_{3}$.

\section{REFERENCES}

FISHER, R. A. 1936.

Use of multiple measurements in taxonomic problems.

Ann. Eugen., 7, 179-188.

SMITH, H. F. 1936 .

A discriminant function for plant selection.

Ann. Eugen., 8, 240-250. 